\title{
Clustering and Switching on Verbal Fluency in Older Adults with Hearing Loss
}

\author{
Soo Jung Lee \\ Department of Communication Disorders, Tongmyong University, Busan, Korea \\ 난청 노년층의 단어 유창성에 나타난 군집과 전환 특성 \\ 이 수 정 \\ 동명대학교 언어치료청각학과
}

\begin{abstract}
Purpose: The purpose of this study was to examine verbal fluency of older adults with hearing loss compared to older adults with normalhearing. Methods: A total of 48 older adults (24 for hearing loss and 24 for normal-hearing) participated. The semantic verbal fluency task were assessed. We analyzed the total number of words generated, clusters, switches and mean cluster size. The hearing-impaired older adults were also evaluated by frontal-executive function tests, which are the Korean-Trail Making Test for the Elderly and the Korean-Color Word Stroop Test. Results: First, the hearing-impaired group produced significantly fewer words than the normal-hearing group, and their production were characterized by fewer switches than the control group. There were no significant differences in the number of clusters and mean cluster size between two groups. Second, for the hearing-impaired group, the total number of words was significantly correlated with number of switches and clusters. On the other hand, in the normal-hearing group, the total number of words was significantly correlated with mean cluster size and number of clusters. Finally, among frontal-executive components, cognitive processing speed was associated with verbal fluency in the hearing-impaired group. Conclusion: Our findings suggest that older adults with hearing loss have lower performance on verbal fluency than their peers with normal-hearing. The decline in frontal lobe functions may adversely affect their verbal fluency.
\end{abstract}

Key Words: Verbal fluency, Hearing impairment, Switching, Clustering, Frontal-executive function.

Received: August 5, 2019 / Revised: August 27, 2019 / Accepted: September 9, 2019

Correspondence: Soo Jung Lee, Department of Communication Disorders, Tongmyong University, 428 Sinseon-ro, Nam-gu, Busan 48520, Korea

Tel: +82-51-629-2138 / Fax: +82-51-629-2019 / E-mail: sjslp@tu.ac.kr

\section{INTRODUCTION}

단어유창성검사는 생성이름대기검사로서 제한된 시간 동안 특정 의미 범주(예: 동물, 가게 물건)에 속하는 단어들이나 특 정 음소(예: ‘'’, 'o', ‘'’)로 시작하는 단어들을 최대한 많이 산 출하도록 하는 검사이다(Kang et al., 2000). 이를 통해 어휘의미지식을 전략적으로 탐색하여 심성 어휘집(mental lexicon) 에 저장되어 있는 단어들을 효율적으로 인출하는 능력을 평가 할 수 있다(Shao et al., 2014; Whiteside et al., 2016). 단어유창 성검사에서 일반적으로 사용하는 평가 측정치는 정반응 수인

(c) This is an Open Access article distributed under the terms of the Creative Commons Attribution Non-Commercial License (https://creativecommons.org/licenses/by-nc/4.0) which permits unrestricted non-commercial use, distribution, and reproduction in any medium, provided the original work is properly cited.
데, 제한된 시간 동안 특정 범주에 속하는 단어를 얼마나 많이 산출하였는가를 평가하게 된다. 그러나 단순히 정반응 수를 세 는 것은 단어 유창성 과제를 수행하는 데 필요한 여러 가지 복 잡한 인지적 처리 과정에 대한 다양한 정보를 파악할 수 없다 는 제한점이 있다(Park et al., 2006). 이를 보완할 수 있는 측정 치가 바로 단어 유창성에서 나타난 '군집(clustering)'과 '전환 (switching)' 능력을 분석하는 것이다(Troyer et al., 1997). 군집 이란 제시된 범주 내의 특정 하위 범주에 속하는 연관 단어들 을 연속적으로 산출하는 능력이며, 전환은 특정 하위 범주의 단어를 모두 인출하고 난 후에 또 다른 하위 범주로 이동하는 것을 의미한다(Troyer et al., 1997). 예컨대 '동물'이라는 의미 범주에 속하는 단어를 산출하도록 하였을 때 '까마귀, 까치, 부 엉이, 잉어, 상어, 고등어'라고 답했다고 가정해 보자. 이때 '새'에 
속하는 '까마귀, 까치, 부엉이'를 연속적으로 산출하거나 '물고 기'에 속하는 '잉어, 상어, 고등어'를 연속적으로 산출하는 것이 군집 능력에 해당한다. 한편 '새’라는 하위 범주에 속하는 단어 들을 모두 산출하고 난 후에 더 이상 단어를 인출해 낼 수 없 을 때 '물고기’라는 또 다른 하위 범주로 이동할 수 있는 능력이 전환이다.

군집과 전환은 각각 서로 다른 인지적 처리 과정에 의존하는 것으로 알려져 있다(Park et al., 2006; Troyer et al., 1997). 군 집은 의미적으로 관련된 단어를 연달아 인출하는 능력이므로 이는 의미기억이 유기적으로 저장되어 있는 측두엽 처리와 주 로 관련이 있다(Ho et al., 2002; Troyer et al., 1998). 한편 전 환은 고갈된 정보를 대체하기 위해 또 다른 정보로 이동하는 능력이므로 이는 인지적 유연성 및 전략적인 정보 탐색 등을 담당하는 전두엽 기능과 주된 관련이 있다(Ho et al., 2002; Troyer et al., 1998). Troyer et al.(1998)의 연구에서는 국소적 전두엽 손상 환자의 경우 정상군에 비해 전환 능력이 저하된 반면 군집에는 차이가 없었고, 국소적 측두엽 손상 환자의 경 우 정상군에 비해 군집 능력이 저하되었을 뿐만 아니라 전환 능력에도 저하를 보이는 것으로 나타났다. 즉, 군집은 주로 측 두엽 기능을, 전환은 주로 전두엽 기능을 반영하지만, 의미적으 로 연관된 단어를 연속적으로 산출하여 군집을 형성하기 위해 서는 측두엽에 저장된 의미정보들을 전략적으로 탐색하고 빠 르게 인출하는 전두엽 처리 역시 수반되어야 함을 알 수 있다 (Moscovitch, 1994).

정상적인 노화 과정에서 단어 유창성이 저하된다는 것은 이 미 널리 알려진 사실이며(Kang et al., 2000; Lee et al., 2015; Mathuranath et al., 2003), 정보 처리 속도의 저하로 인하여 단 어 인출에 걸리는 시간이 증가하고 이로 인하여 제한된 시간 동 안 산출하는 총 단어의 수도 줄어들게 된다(Lee et al., 2015). 이처럼 정상 노화로 인한 단어 유창성의 저하는 의미기억의 손 상이나 의미지식 자체의 문제에 기인하기보다는 전반적인 인지 처리 과정의 효율성 저하에 기인한다고 볼 수 있다(Peach \& Shapiro, 2012). 치매나 파킨슨병과 같은 신경학적 질환군의 경 우에서도 단어 유창성 능력이 저하되는 것으로 알려져 있다 (Henry \& Crawford, 2004; Lee \& Kim, 2019; Lee et al., 2018). 알츠하이머 치매의 경우 정상 노인에 비해 경도 치매 환 자의 단어 유창성이 저하되고, 중등도 치매가 경도 치매보다 뚜 렷하게 더 낮은 수행력을 보이며, 특히 여러 가지 인지 영역 가 운데 집행기능의 저하가 치매 환자의 단어 유창성에 영향을 주 는 주된 요인으로 밝혀졌다(Lee \& Kim, 2019). 파킨슨병 환자 군의 경우에도 정상군에 비해 단어 유창성이 저하되는데, 특히 관련성이 있는 어휘 목록들을 연속적으로 인출하는 전략이 저 하되어 군집 능력의 저하가 두드러지는 것으로 나타났다(Lee et al., 2018).

이와 같이 국내외를 막론하고 정상 노화나 신경학적 질환 등 에 의한 단어 유창성 능력의 변화에 주목하는 연구들은 풍부 한 반면, 대표적인 감각신경성 질환의 하나인 난청을 않고 있는 노년층의 단어 유창성을 살펴본 연구는 매우 드물며 국내에서 는 전무하다. 몇몇 국외 연구를 살펴보면 난청 노인 집단의 단어 유창성검사(동물 이름대기 과제) 수행력이 정상 청력의 집단에 비해 유의하게 낮은 것으로 나타난 바 있으나 군집과 전환 능력 에 대한 분석은 이루어지지 않았다(Deal et al., 2015). Classon et al.(2014)은 연구 대상자를 노년층에 한정하지 않고 난청 성인 을 대상으로 의미유창성검사와 음소유창성검사를 모두 실시하 여 군집과 전환 능력을 분석하였는데, 의미유창성검사와 음소 유창성검사의 양상이 다소 상이하게 나타났다. 의미유창성검 사에서는 난청 집단과 정상 청력 집단 간 단어 유창성 측정치 에 유의한 차이가 없는 반면, 음소유창성검사에서는 난청 집단 이 정상 집단에 비해 총 산출 단어 수 및 전환 수가 유의하게 적 었다. 이러한 결과에 대해 연구자들은 난청으로 인한 전반적인 음운지식 및 음운기술의 저하가 음소 유창성 과제 수행력에 부 정적인 영향을 미친 것으로 해석하였다. 단, Classon et al.(2014) 의 연구에서는 대상자 선정 시 정상 인지기능에 대한 선별검사 가 이루어지지 않아 인지장애가 있는 난청인이 연구에 포함되었 을 가능성이 있으므로 단어 유창성에 대한 난청의 영향을 파 악하기에 다소 제한이 있다. 이와 같이 선행연구의 부족으로 인하여 난청 노년층의 단어 유창성 능력은 아직까지 명확히 밝 혀지지 못한 측면이 있다.

이에 본 연구에서는 난청 노년층의 단어 유창성에 대해 살펴 보고자 하며, 구체적인 연구목표는 다음과 같다. 첫째, 난청 노 인과 정상 청력의 노인 집단 간에 단어 유창성 과제의 수행력 에 차이가 있는지 살펴보되, 총 산출 단어 수뿐만 아니라 군집 (군집 수, 평균 군집 크기)과 전환(전환 수) 능력을 비교하고자 하였다. 둘째, 각 집단별로 단어 유창성 과제의 총 산출 단어 수와 군집 수, 군집 크기, 전환 수 간에 어떠한 상관을 보이는지 살펴보고 집단 간 차이가 있는지 비교하고자 하였다. 셋째, 난 청 노인 집단의 단어 유창성과 전두엽-집행기능 간에 상관이 있는지 살펴보고자 하였다. 본 연구를 통해 국내 난청 노인의 단어 유창성 능력을 살펴보고, 특히 군집과 전환 분석을 통해 기저의 인지 처리 과정에 주목할 수 있을 것으로 기대한다.

\section{MATERIALS AND METHODS}

\section{연구 대상}

본 연구는 난청 노인 24명과 정상 청력 노인 24명의 총 48명 을 대상으로 실시하였다. 실험 집단인 난청 노인은 부산시에 위 
치한 청각재활센터를 내원한 자로, 1) 연령이 만 60세 이상이 며, 2) 기초건강 선별을 위한 설문에서 신경학적(예: 뇌졸중, 치 매, 파킨슨병 등), 정신적(예: 우울증 등) 질환의 병력이 없고 난 청 외 이명, 어지러움 등을 호소하지 않으며, 3) 순음청력검사 (AD629, Interacoustics A/S, Middelfart, Denmark) 500, $1,000,2,000 \mathrm{~Hz}$ 주파수의 평균순음역치가 $26 \mathrm{~dB} \mathrm{HL}$ 이상이 고 양측 귀의 평균순음역치 차이가 $20 \mathrm{~dB} \mathrm{HL}$ 이내로 대칭적 이며, 기도-골도 청력 역치가 $10 \mathrm{~dB} \mathrm{HL}$ 이내로 고막운동도검 사(AT235, Interacoustics A/S)에서 중이의 상태가 정상이며, 4) 일측 혹은 양측 귀에 보청기를 착용하고 있으며, 5) 한국판 간이정신상태검사(Korean-Mini Mental State Examination, K-MMSE)의 점수가 연령 및 교육 연수 규준 비교 시에 -1 표 준편차 이내로 정상 범주에 해당하고(Kang, 2006), 6) 교육 연 수가 최소 6년 이상인 자로 선정하였다.

대조집단인 정상 청력 노인의 선정기준은 1) 연령이 만 60세 이상이며, 2) 기초건강 선별을 위한 설문에서 신경학적, 정신적 질환 등의 병력이 없고, 3) 순음청력검사상 평균순음역치가 25 $\mathrm{dB} \mathrm{HL}$ 이내로 정상 청력을 나타내며, 4) $\mathrm{K}-\mathrm{MMSE}$ 의 점수가 정상 범주에 해당하고(Kang, 2006), 5) 교육 연수가 최소 6년 이 상인 자로 선정하였다. 학력이 인지검사에 미치는 영향을 최소 화하기 위하여 두 집단 모두 교육 연수를 최소 6년 이상으로 제 한하였으며, 두 집단 모두 유효성 평가를 시행할 수 없을 정도로 시력 및 청력장애가 심한 경우, 예컨대 시각 보조기구를 착용하 고도 글자를 읽을 수 없거나 보청기를 착용하고도 조용한 환경 에서 일상생활 대화가 불가능한 경우 대상자에서 제외하였다.

각 집단별 인구통계학적 특성 및 청력검사 결과는 Table 1에 제시하였다. 단어 유창성에 영향을 미치는 것으로 알려진 연령 및 성별, 교육 연수를 살펴보면 두 집단 간 성별 및 교육 연수에 는 통계학적으로 유의한 차이가 없었으나, 연령에는 유의한 차이 를 보였다 $(t=8.198, p<0.01)$. 노년층의 경우 연령이 높아질수 록 노인성 난청을 나타낼 가능성이 높아지기 때문에(Homans et al., 2017), 본 연구에서도 난청 노인 집단이 정상 청력의 노인 집단에 비해 더 높은 연령 분포를 나타낸 것으로 보인다. 두 집

Table 1. Demographic characteristics of two groups

\begin{tabular}{lccc}
\hline \multicolumn{1}{c}{ Characteristic } & $\mathrm{HI}(\mathrm{n}=24)$ & $\mathrm{NH}(\mathrm{n}=24)$ & $p$-value \\
\hline Age (yr) & $76.83 \pm 5.49$ & $65.54 \pm 3.91$ & $0.000^{\dagger}$ \\
Gender (m:f) & $16: 8$ & $12: 12$ & 0.251 \\
Education level (yr) & $9.50 \pm 3.21$ & $11.39 \pm 4.61$ & 0.106 \\
K-MMSE & $27.83 \pm 1.40$ & $28.79 \pm 1.17$ & $0.014^{*}$ \\
Right-sided PTA (dB HL) & $55.62 \pm 11.72$ & $18.54 \pm 4.46$ & $0.000^{\dagger}$ \\
Left-sided PTA (dB HL) & $55.98 \pm 9.02$ & $17.23 \pm 5.12$ & $0.000^{\dagger}$ \\
\hline
\end{tabular}

${ }^{*} p<0.05,{ }^{\dagger} p<0.01$. HI: hearing impairment, NH: normal-hearing, K-MMSE: Korean-Mini Mental State Examination, PTA: puretone threshold average
단 모두 K-MMSE 규준 비교 시에 인지기능이 정상 범주에 속 하는 자로 선정기준을 정하였으나, 집단 간 $\mathrm{K}-\mathrm{MMSE}$ 점수에 서 약간의 차이가 나타났는데 $(t=-2.561, p<0.05)$, 이는 집단 간 연령 차이에서 비롯할 가능성이 있다. 청력의 경우, 오른쪽 귀와 왼쪽 귀의 평균순음역치에서 집단 간 유의한 차이를 확인 하였다 $(t=14.479, p<0.01 ; t=18.289, p<0.01)$.

\section{연구 도구}

\section{단어 유창성 평가}

본 연구에서는 의미 범주의 단어 유창성 과제를 시행하였으 며, 피험자로 하여금 제한된 시간(1분) 동안 ‘동물’이라는 의미 적 범주에 해당하는 단어를 최대한 많이 산출하도록 하였다 (Kang et al., 2000). 본 연구에서는 선행연구에 근거하여 단어 유창성을 평가하는 측정치로서 총 4가지, 즉, 산출한 총 단어 수(total number of words), 군집 수(number of clusters), 전환 수(number of switches), 평균 군집 크기(mean cluster size)를 산출하였다(Classon et al., 2014; Lee et al., 2018; Park et al., 2006; Troyer et al., 1997). 첫째, 총 단어 수의 경우 반복하여 산출한 단어들은 한 번만 정반응으로 인정하였고, 범주에 속하 지 않은 반응이나 고유명사는 정반응에서 제외하였으며, 파생 어의 경우는 제일 첫 반응만 정반응으로 채점하였다. 상위개념 어와 하위개념어를 함께 산출한 경우, 예컨대, 새, 까치, 까마 귀, 제비'라고 산출한 경우에는 하위개념에 속하는 단어들, 즉, '까치, 까마귀, 제비'만 정반응으로 인정하고, 상위개념어인 '새' 는 정반응에서 제외하였다. 둘째, 군집 수는 1 분 동안 산출한 단어들에서 형성된 군집의 수를 세어 산출하였다. 군집이란 의 미적으로 동일한 하위 범주 내에서 두 개 이상의 단어를 연속적 으로 산출한 경우에 해당한다. 예컨대, '동물'이라는 범주 안에서 도 '새'에 해당하는 동물을 두 개 이상 연속적으로 산출하거나 '물속에 사는 동물을 두 개 이상 연속적으로 산출할 때에 군집 이 형성된다. 셋째, 군집 크기란 한 군집 내의 단어를 세어 산출 하는데, 이때 연속적으로 단어를 산출하지 못하고 한 개 단어 만을 산출할 경우 군집 크기는 0이며, 두 개의 단어를 연속적 으로 산출할 경우 군집 크기는 1이 되며, 세 개의 단어를 연속 적으로 산출할 경우에는 군집 크기가 2가 되는 식이다. 이렇게 각각의 군집 크기를 모두 더한 후 이를 총 군집 수로 나누어 평 균 군집 크기를 산출하였다. 넷째, 전환 수는 하나의 하위 범주 에서 또 다른 하위 범주로 이동한 횟수를 세어 산출하였다. 하 나의 군집에서 다른 군집으로 이동한 경우뿐만 아니라, 한 단 어에서 다른 하위 범주의 한 단어로 이동한 경우도 전환 수에 포함하였다(Troyer et al., 1997). 선행연구에서와 같이 반복 오 류는 총 단어 수를 산출할 때에는 반응에서 제외하였으나, 군 
집 수, 전환 수, 평균 군집 크기를 산출할 때에는 반응으로 포 함하여 분석하였다(Park et al., 2006; Troyer et al., 1997).

'동물'의 하위 범주 분류로는 서식 환경에 따라서 '동물원에 서 볼 수 있는 동물, '물속에 사는 동물, '야생동물로 분류하였 고, 동물 종류에 따라서 '포유류', '조류, '어류', '양서류/파충류', '영장류, '설치류', '곤충류', '무척추동물로 분류하였고, 인간의 사용 방식에 따라서 '애완동물, '농장동물(가축)', '짐을 드는 동 물로 분류하였다. 이는 선행연구(Kim, 2016; Troyer et al., 1997) 의 분류를 대부분 따른 것이나, 본 연구에서는 하위 범주에 '기 타를 추가하여 한국 문화권에서 의미적 연결성이 강한 단어들 (예: 토끼, 거북이)이나 쌍을 이루어 주로 학습하게 되는 단어 들(예: 고양이, 쥐)을 추가하였다. '동물'의 하위 범주 분류 및 예 시는 Appendix에 제시하였다.

단어 유창성 자료 분석의 예시를 들자면 대상자가 사자, 호 랑이, 곰, 원숭이, 닭, 소, 돼지, 뼈꾸기, 학, 부엉이, 당나귀, 말, 개미'로 산출했을 경우 총 산출 단어 수는 13 개이다. 군집 수는 동물의 하위 범주 중 '동물원에서 볼 수 있는 동물(사자, 호랑이, 곰, 원숭이)', '가축(닭, 소, 돼지), '조류(빼꾸기, 학, 부엉이)', '짐을 드는 동물(당나귀, 말)'로 총 4개이다. 이때 '개미'는 동물의 하위 범주 중 '곤충에 해당하나 두 개 이상의 단어를 연속적으로 산 출하지 않고 '곤충'이라는 하위 범주에서 한 단어만 산출하였으 므로 군집 수에 포함시키지 않는다. 평균 군집 크기는 각각의 군 집 크기를 모두 더한 값, 즉, $3+2+2+1=8$ 을 총 군집 수 4 로 나누어 산출하므로 2 가 된다. 전환 수는 하나의 하위 범주에서 다른 하위 범주로 이동한 횟수이므로 4 가 된다. 분석 시 두 하위 범주에 걸쳐 모두 해당되는 반응들은 두 하위 범주 모두에 각각 포함시켰는데(Troyer et al., 1997), 예컨대 사자, 호랑이, 사슴, 타 조, 참새, 까마귀, 비둘기'에서 '타조는 첫 번째 하위 범주인 '동물 원에서 볼 수 있는 동물'과 두 번째 하위 범주인 '조류’에 모두 포함 되기 때문에 두 하위 범주 모두에 각각 정반응으로 포함시켰다.

\section{전두엽-집행기능 평가}

난청 노인의 전두엽-집행기능을 평가하고자 서울신경심리검 사2판(Kang et al., 2012)의 전두엽-집행기능 영역에 포함되어 있는 검사들 가운데 한국판 노인용 기호잇기검사(Korean-Trail Making Test for the Elderly, K-TMT-E) (Yi et al., 2007)와 한 국판 스트룹 검사(Korean-Color Word Stroop Test, K-CWST) (Lee et al., 2000)를 시행하였다. 첫째, K-TMT-E는 숫자만으 로 구성된 $\mathrm{A}$ 형과 숫자와 글자가 섞여 있는 $\mathrm{B}$ 형으로 구성되어 있다. A형은 피험자로 하여금 무작위로 배치된 1 부터 15 까지의 숫자를 순서대로 잇게 하는데 검사자는 피험자가 선을 다 이을 때까지의 시간을 측정한다. B형은 숫자와 글자(요일)를 번갈아 가면서 선을 잇는데 마찬가지로 선을 다 이을 때까지의 시간을
측정한다. 본 연구에서 $\mathrm{K}-\mathrm{TMT}-\mathrm{E}$ 의 수행력은 검사를 시작하 고부터 선 잇기를 완성할 때까지의 반응시간을 재어 산출하였 으며, 반응시간이 길수록 수행력이 낮다는 것을 뜻한다. 둘째, $\mathrm{K}-\mathrm{CWST}$ 는 글자읽기 및 색깔읽기 과제로 구성되어 있다. 글자 읽기 과제의 경우 피험자는 글자가 적혀진 색깔과 글자의 뜻이 서로 일치되지 않는 112 개의 자극 단어(예: "빨강이라는 글자가 노란색 잉크로 적혀 있음)를 제한된 시간(120초) 내 읽도록 하 며, 112 개의 자극을 다 읽을 때까지 걸린 반응시간을 측정한다. 색깔읽기 과제의 경우 글자읽기 과제와 마찬가지로 글자가 적 혀진 색깔과 글자의 뜻이 서로 일치되지 않는 112 개의 자극 단 어가 주어지나, 글자읽기 과제와 달리 글자가 아닌 글자가 쓰여 진 색깔 이름을 제한된 시간 내 읽도록 한다. 글자읽기와 동일 하게 112 개의 자극을 다 읽을 때까지 걸린 반응시간을 측정한 다. 글자 및 색깔읽기 과제 모두 120 초가 경과해도 112 개의 자 극을 다 읽지 못하면 검사를 중지하고 120 초가 경과했을 때까 지의 정반응 수와 오반응 수를 기록한다. 본 연구에서는 글자 읽기와 색깔읽기 각각의 정반응 점수 및 반응시간을 산출하였 으며, 정반응 점수는 높을수록 수행력이 높고, 반응시간은 길 수록 수행력이 낮다는 것을 의미한다.

\section{연구 절차}

일차적으로 대상자가 선정기준에 부합하는지 선별하기 위하 여 기초건강 선별 설문지를 시행하였으며, 연령 및 성별, 교육 연수, 직업, 손잡이 등의 기본 정보를 수집하기 위한 면담이 이 루어졌다. 다음으로 청력검사실의 방음실에서 순음청력검사 및 어음청력검사, 고막운동도검사를 통해 대상자의 청력 수준 및 보청기 사용 여부 등을 확인하였다. 선정기준에 부합하는 경우 에 한해 K-MMSE를 통한 전반적인 인지능력 확인 및 단어 유 창성 평가가 이루어졌다. 전두엽-집행기능 평가의 경우 실험군 인 난청 노인 집단을 대상으로만 시행되었다. 모든 언어-인지 검사는 조용한 방에서 검사자와 피험자 간 일대일 방식으로 이 루어졌으며, 피험자는 반응지에 직접 응답하거나, 피험자가 구 두로 응답하는 과제인 경우에는 검사자가 피험자의 반응을 실 시간으로 기록하는 동시에 보이스 레코더로 녹음하였다. 단어 유창성 과제의 경우, 녹음 파일을 2 회 이상 반복 청취하여 실시 간으로 기록한 피험자의 반응과 대조하며 재확인하는 절차를 거쳐 분석하였다.

\section{평가자 간 신뢰도}

언어병리학 전공 박사 1 명에게 단어유창성검사 절차 및 분석 방법(총 산출 단어 수, 군집 수, 전환 수, 평균 군집 크기)을 자 세히 설명한 후 전체 표집된 자료의 약 $15 \%$ (7명)를 임의 선정 하여 평가자 간 신뢰도(inter-rater reliability)를 구하였다. 그 
결과 단어 유창성 평가 측정치 가운데 총 단어 수, 군집 수, 전 환 수는 각각 평가자 간 일치율 $100 \%$ 를 보였고, 평균 군집 크 기는 약 $85.7 \%$ 의 일치율을 나타내었다.

\section{통계 분석}

자료의 통계 처리는 SPSS 프로그램(Ver. 25, IBM Corp., Armonk, NY, USA)을 사용하였다. 첫째, 집단 간 인구통계학적 특성의 차이를 알아보기 위하여 독립표본 $t$-검정을 실시하였 다. 둘째, 집단 간 단어 유창성 평가 측정치, 즉, 총 산출 단어 수, 군집 수, 전환 수, 평균 군집 크기를 비교하기 위하여 연령 및 교육 연수를 공변량으로 한 공분산 분석(analysis of covariance)을 실시하였다. 셋째, 단어 유창성 과제에서 총 산출 단 어 수와 나머지 세 가지 측정치 간의 상관성을 알아보기 위하여 각 집단별로 피어슨 상관계수(Pearson correlation coefficient) 분석을 시행하였다. 넷째, 난청 노인 집단에서 단어 유창성 과 제의 총 산출 단어 수와 전두엽-집행기능 간 상관성을 알아보 기 위하여 연령을 제어변수로 한 부분상관계수(partial correlation coefficient) 분석을 시행하였다. 이때 난청 노인 집단에 속한 총 24명 가운데 K-CWST에서 색깔 지각 능력의 저하가 의심되는 1 명을 제외한 총 23 명을 분석 대상으로 하였다.

\section{RESULTS}

\section{집단 간 단어 유창성 비교}

난청 노인과 정상 청력의 노인 집단 간 단어 유창성 능력을 비교하기 위해 연령 및 교육 연수를 공변량으로 설정하여 공분 산 분석을 실시하였다. 그 결과, 첫째, 두 집단 간 총 산출 단어 수에는 통계적으로 유의한 차이가 나타났으며, 난청 노인 집단 이 정상 청력의 노인 집단에 비해 총 산출 단어 수가 유의하게 적었다 $(\mathrm{F}=4.320, p<0.05)$. 둘째, 전환 수에서도 두 집단 간 에 통계적으로 유의한 차이가 나타났으며, 난청 노인 집단이 정 상 청력의 노인 집단에 비해 전환 수가 유의하게 적었다 $(\mathrm{F}=$ 4.209, $p<0.05$ ). 셋째, 군집 수와 평균 군집 크기에서는 두 집단 간 에 통계적으로 유의한 차이가 없는 것으로 나타났다 $(\mathrm{F}=0.601$, $p=0.442 ; \mathrm{F}=0.075, p=0.786$. 단어 유창성 측정치에 대한 집 단 간 비교는 Figure 1과 Table 2에 제시하였다.

\section{집단별 총 산출 단어 수와 군집 수, 전환 수, 평균 군집 크기 간 상관관계}

집단별로 총 산출 단어 수와 군집 수, 전환 수, 평균 군집 크 기 간 상관성을 알아보기 위해 상관 분석을 실시하였다. 그 결 과 난청 노인 집단의 경우 총 산출 단어 수와 전환 수 간 $(\mathrm{r}=$ $0.631, p<0.01)$, 총 산출 단어 수와 군집 수 간(r $=0.689, p<$

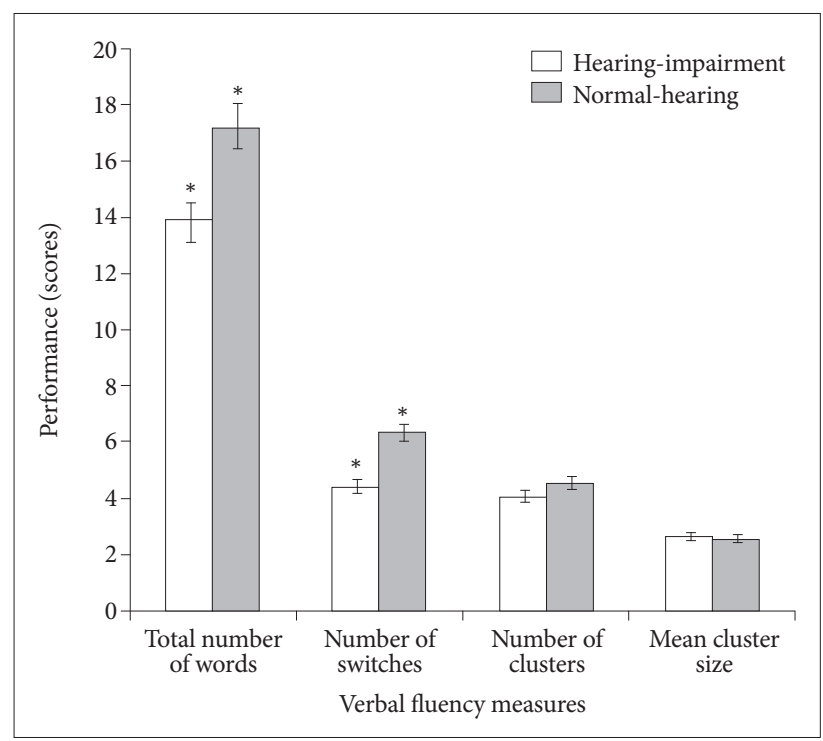

Figure 1. Covariate-adjusted means and standard errors of verbal fluency measures for two groups. ${ }^{*} p<0.05$.

Table 2. Covariate-adjusted means and standard errors of verbal fluency measures for two groups

\begin{tabular}{lrrc}
\hline \multicolumn{1}{c}{ Measures } & HI $(\mathrm{n}=24)$ & $\mathrm{NH}(\mathrm{n}=24)$ & $p$-value \\
\hline Total number of words & $13.84 \pm 0.96$ & $17.23 \pm 0.96$ & $0.044^{*}$ \\
Number of clusters & $4.04 \pm 0.38$ & $4.54 \pm 0.38$ & 0.442 \\
Number of switches & $4.40 \pm 0.55$ & $6.34 \pm 0.55$ & $0.046^{*}$ \\
Mean cluster size & $2.65 \pm 0.26$ & $2.53 \pm 0.26$ & 0.786 \\
\hline
\end{tabular}

${ }^{*} p<0.05$. HI: hearing-impairment, NH: normal-hearing

Table 3. Correlation coefficients between total number of words and other measures of verbal fluency for two groups

\begin{tabular}{lcc}
\hline \multirow{2}{*}{ Measures } & \multicolumn{2}{c}{ Total number of words } \\
\cline { 2 - 3 } & $\mathrm{HI}(\mathrm{n}=24)$ & $\mathrm{NH}(\mathrm{n}=24)$ \\
\hline Number of clusters & $0.689^{\dagger}$ & $0.507^{*}$ \\
Number of switches & $0.631^{\dagger}$ & 0.382 \\
Mean cluster size & -0.096 & $0.505^{*}$ \\
\hline${ }^{*} p<0.05{ }^{\dagger} p<0.01 . \mathrm{HI} \cdot$ hearing-impairment $\mathrm{NH}$ :
\end{tabular}

0.01)에 유의한 정적 상관이 나타났으며, 총 산출 단어 수와 평 균 군집 크기 간에는 유의한 상관이 나타나지 않았다 $(\mathrm{r}=-0.096$, $p=0.655)$. 정상 청력 노인 집단의 경우 총 산출 단어 수와 군 집 수 간 $(\mathrm{r}=0.507, p<0.05)$, 총 산출 단어 수와 평균 군집 크 기 간 $(\mathrm{r}=0.505, p<0.05)$ 에 유의한 정적 상관이 나타났으며, 총 산출 단어 수와 전환 수 간에는 유의한 상관이 나타나지 않 았다 $(\mathrm{r}=0.382, p=0.065)$. 집단별 총 산출 단어 수와 군집 수, 전환 수, 평균 군집 크기 간 상관 분석 결과는 Table 3에 제시하 였다.

\section{난청 노인의 단어 유창성과 전두엽-집행기능 간 상관관계}

난청 노인의 단어 유창성과 전두엽-집행기능 간 상관성을 알 
Table 4. Correlation coefficients between total number of words generated on verbal fluency and frontal-executive measures for the hearing-impaired group

\begin{tabular}{lc}
\hline \multicolumn{1}{c}{ Measures } & $\begin{array}{c}\text { Total number of } \\
\text { words }\end{array}$ \\
\cline { 2 - 2 } & $\mathrm{HI}(\mathrm{n}=23)$ \\
\hline K-TMT-E: part A reaction time $(\mathrm{sec})$ & $-0.430^{*}$ \\
K-TMT-E: part B reaction time (sec) & 0.171 \\
K-CWST: word reading time (sec) & -0.273 \\
K-CWST: color reading time (sec) & -0.143 \\
K-CWST: correct responses on word reading & 0.207 \\
K-CWST: correct responses on color reading & 0.119 \\
\hline
\end{tabular}

${ }^{*} p<0.05$. HI: hearing impairment, K-TMT-E: Korean-Trail Making Test for the Elderly, K-CWST: Korean-Color Word Stroop Test

아보기 위해 연령을 제어변수로 한 부분 상관 분석을 실시하였 다. 그 결과 총 산출한 단어 수와 $\mathrm{K}-\mathrm{TMT}-\mathrm{E}$ 의 $\mathrm{A}$ 형 반응시간 간 에 유의한 부적 상관이 나타났다 $(\mathrm{r}=-0.430, p<0.05)$. 그 외 전두엽-집행기능 검사 측정치들, 즉, $\mathrm{K}-\mathrm{TMT}-\mathrm{E}$ 의 $\mathrm{B}$ 형 반응시 간, $\mathrm{K}-\mathrm{CWST}$ 의 글자읽기 정반응 점수 및 반응시간, $\mathrm{K}-\mathrm{CWST}$ 의 색깔읽기 정반응 점수 및 반응시간과는 유의한 상관성이 나 타나지 않았다. 난청 노인의 단어 유창성과 전두엽-집행기능 간 상관 분석 결과는 Table 4에 제시하였다.

\section{DISCUSSIONS}

본 연구에서는 난청 노인과 정상 청력 노인 집단 간에 단어 유창성 과제의 수행력에 차이가 있는지 살펴보되, 총 산출 단 어 수뿐만 아니라 군집(군집 수, 평균 군집 크기)과 전환(전환 수) 능력을 분석하여 비교하였다. 연구 결과 난청 노인은 정상 청력 노인에 비해 단어 유창성 평가 측정치 중 총 산출 단어 수 와 전환 수에서 저하된 수행력을 보였는데, 이러한 결과는 난청 노인의 저하된 단어 유창성 능력이 주로 전두엽 기능 저하에 기인할 가능성이 높음을 시사한다. 전환은 특정 범주에 속하 는 정보들이 고갈되었을 때 다른 하위 범주로 이동하는 능력으 로 주로 전두엽 기능에 의존하는 것으로 알려져 있으며(Park et al., 2006; Troyer et al., 1997, 1998), 관련 정보를 전략적으로 탐색하여 생각을 빠르게 전환할 수 있는 인지적 유연성(cognitive flexibility)이 중요시된다(Park \& Yoon, 2015; Shao et al., 2014). 인지적 유연성은 간섭통제(interference control), 반응억 제(response inhibition), 작업기억(working memory)과 더불어 전두엽이 주로 담당하는 집행기능의 핵심 요소이다(Diamond, 2013; McCabe et al., 2010). 단어 유창성 과제를 성공적으로 수행하기 위해서는 인지적 유연성뿐만 아니라 억제나 작업기억 등의 집행기능 요소들이 요구되는데, 해당 범주에 속하지 않는 관련 없는 단어의 활성화는 억제하면서 제시된 범주 내의 관련
정보만을 전략적으로 탐색해야 하며, 반복 오류를 범하지 않기 위해서 이미 산출한 단어는 기억에 저장하는 동시에 새로운 단 어를 지속적으로 인출해야 하기 때문이다(Henry \& Crawford, 2004; Shao et al., 2014). 난청과 인지기능 간 관련성에 대한 메 타 분석 연구에 따르면 난청이 있는 장노년층은 정상 청력의 대 조군에 비해 시공간 능력을 제외한 대부분의 인지 영역, 즉, 전 반적 인지기능, 집행기능 및 정보 처리 속도, 작업기억, 언어능력, 언어적 기억력에서 모두 수행력이 저하되었으며, 특히, 집행기능 및 정보 처리 속도와 작업기억은 언어능력이나 언어적 기억력에 비해서 더 큰 효과 크기를 나타내었다(Lee, 2018). 본 연구에서 는 난청 노인이 정상 노인 집단에 비해 총 산출 단어 수와 전환 수에서 저하된 수행력을 보인 반면 군집 능력에는 두 집단 간 유의한 차이가 나타나지 않았다. 이는 난청 노인의 단어 유창성 능력 저하가 주로 전두엽 기능 저하에서 비롯할 수 있음을 뒷받 침하는 근거가 될 수 있다. 군집 능력은 의미적으로 관련된 단어 를 연속해서 인출하는 능력으로, 의미기억이 유기적으로 저장되 어 있는 측두엽 기능과 주로 관련된다(Park et al., 2006; Troyer et al., 1997, 1998). 즉, 난청 노인의 단어 유창성 저하는 의미기 억이나 심성 어휘집 자체의 문제에 기인한다기보다 이를 전략적 으로 탐색하여 효과적으로 인출하지 못하는 것에서 비롯한다고 볼 수 있겠다.

난청 노인 집단의 경우 단어 유창성 과제의 총 산출 단어 수 는 전환 수 및 군집 수와 정적 상관을 보였는데, 즉, 새로운 하 위 범주로의 전환이 많을수록 더 많은 단어를 산출하는 경향 이 나타났다. 이는 한 군집 내에서 더 이상 새로운 정보의 인출 이 어려울 때 지체하지 않고 다른 하위 범주로 빠르게 이동할 수록 더 높은 수행력을 보였음을 의미한다. 한편 정상 노인 집 단은 난청 집단과는 다소 다른 양상을 보였는데, 총 산출 단어 수와 평균 군집 크기 및 군집 수에서 정적 상관을 나타냈으며 전환 수에서는 유의한 상관을 보이지 않았다. 이는 동일 군집 내에서 의미적으로 관련된 단어들을 연속적으로 산출할수록 전체적으로 더 많은 단어를 산출하는 경향이 있었음을 보여준 다. 이러한 결과는 난청 노인 집단의 경우 전환 능력, 즉 전두엽 기능이 난청 노인의 단어 유창성 능력과 핵심적인 관련성이 있 음을 시사한다. 반면 정상 청력 집단의 경우 단어 유창성 능력 과 어휘지식 및 전두엽 기능 간에 전반적인 상관이 있는 것으 로 해석 가능한데, 왜냐하면 군집 능력이 측두엽 기능에 주로 의존하기는 하지만 측두엽에 저장된 의미정보들을 전략적으로 탐색하고 빠르게 인출하기 위해서는 전두엽 처리 역시 수반될 필요가 있기 때문이다(Moscovitch, 1994).

본 연구에서는 난청 노인의 단어 유창성 능력과 집행기능 간 상관성을 알아보기 위해 난청 노인을 대상으로 서울신경심리검 사2판에 수록되어 있는 집행기능 검사 두 가지, 즉, $\mathrm{K}-\mathrm{TMT}-\mathrm{E}$ 
와 K-CWST를 실시한 후 단어 유창성 과제의 총 산출 단어 수 와 집행기능 검사의 수행력 간 상관성을 분석하였다. 그 결과 정신운동 속도(psychomotor speed)를 주요하게 반영하는 것으 로 알려진(Park et al., 2007) K-TMT-E의 A형 반응시간과 유 일하게 정적 상관이 나타났다. 앞서 설명한 바와 같이 단어 유 창성 과제를 수행하기 위해서는 제한된 시간 내에 관련 정보를 전략적으로 빠르게 인출해내는 것이 필요하다(Peach \& Shapiro, 2012). 즉, 한 군집 내에서 다른 군집으로 빠르게 전환하거 나, 한 군집 내에서도 유기적으로 연결된 관련 정보를 빠르게 산출해내는 능력이 필수적으로 요구된다. Salthouse(2005)에 따르면 단어 유창성 수행력은 다섯 개의 주요 인지능력(추론, 공간시각화, 일화기억, 지각속도, 어휘지식) 가운데 지각속도 (perceptual speed ability)와 유의한 상관을 나타냈다. 정상 및 치매 노년층의 단어 유창성 능력을 확인한 선행연구에서도 TMT A형의 반응시간은 단어 유창성 수행력과 강한 정적 상관 을 보였다(Lee \& Kim, 2019). 단, 본 연구에서 나타난 예상치 못한 결과는 K-TMT-E의 B형 반응시간이나 스트룹 검사의 색깔읽기 과제 수행력(정반응 점수 및 반응시간) 등과는 유의 한 상관이 나타나지 않았다는 점이다. K-TMT-E의 B형은 무 작위로 배열된 숫자와 글자를 번갈아 이어야 하는 과제로 $\mathrm{A}$ 형 에 비해 인지적 유연성 및 주의력 전환 등의 집행기능 요소를 더욱 반영한다(Park et al., 2007). 더불어 스트룹 검사의 색깔 읽기 과제 역시 자동적 처리에 해당하는 글자 정보에 대한 활 성화를 억제하고 색깔에만 주의 집중하여 읽기를 이어나가야 한다는 점에서 인지적 억제나 선택적 주의력 등의 집행기능 요 소를 반영한다(Lee et al., 2000; Scarpina \& Tagini, 2017). 난 청 노인을 대상으로 한 관련 선행연구가 부족하여 직접적으로 연구 결과를 비교하는 것이 어렵기는 하나, 주로 인지 처리 속도 의 지표가 되는 $\mathrm{A}$ 형 반응시간에서만 정적 상관이 나타난 본 연 구 결과는 추후 후속 연구를 통해 재확인이 필요한 부분이다.

정리하자면 본 연구는 군집과 전환에 대한 세부적인 분석을 거쳐 난청 노인의 단어 유창성 능력이 정상 청력 노인에 비해 저하된다는 점을 밝히고, 난청 노인의 저하된 단어 유창성이 주로 전두엽 기능 저하에서 비롯할 가능성이 있음을 밝혔다는 측면에서 의의가 있다. 최근 들어 난청 노인에서 나타나는 인지 기능 저하의 기전을 규명하고자 하는 여러 가지 시도가 이루어 지고 있는데, Wayne \& Johnsrude(2015)는 난청과 인지저하 간 관련성을 설명하는 하나의 새로운 틀(framework)을 제시한 바 있다. 즉, 노화로 인한 뇌 구조 및 기능의 변화는 인지기능 감퇴 및 감각기능의 저하를 야기하는데, 이때 감각기능의 저하로 인 해 증가된 '지각적 어려움(perceptual difficulty)'이 인지기능 저 하를 촉진하게 되고, 인지기능 저하는 다시 지각적 어려움을 높 이며 이 두 가지 요인이 상호 간에 부정적 영향을 미친다는 것이
다. 또한 지각적 어려움이 우울증 등의 정신적 문제들을 야기하 여 이것이 다시 인지기능에 악영향을 미치게 된다는 점을 설명 하였다. 이때 '지각적 어려움'에 주요하게 관여하는 인지기능이 바로 전두엽 기능, 즉, 집행기능이나 주의력, 정보 처리 속도 등 이라는 점(D’Ausilio et al., 2012; Lee et al., 2018; Rönnberg et al., 2010; Wild et al., 2012)을 고려할 때 본 연구의 결과와도 일맥상통하는 측면이 있다. 추후 뇌영상 검사 등을 활용한 후 속 연구를 통해 난청 환자의 전두엽 활성화 정도 및 관련 언어인지능력과의 연관성을 살펴볼 수 있다면 본 연구 결과를 뒷받 침할 수 있을 뿐만 아니라, 난청 노인에서 나타나는 인지저하의 기전을 설명하는 근거가 될 수 있을 것으로 기대한다.

끝으로 몇 가지 측면에서 본 연구의 제한점을 살펴보고자 한 다. 첫째, 본 연구에서는 단어 유창성 과제 중 의미유창성검사 만 시행하고 음소유창성검사는 시행하지 않았다. 난청 성인에 서 의미 유창성 과제의 수행력과 음소 유창성 과제의 수행력이 상이할 수 있음을 밝힌 선행연구(Classon et al., 2014)를 고려 할 때, 추후 연구에서는 두 가지 과제를 모두 포함하여 단어 유 창성 능력을 확인하는 것이 필요하다. 둘째, 본 연구에서는 난 청 노인 집단에 대해서만 단어 유창성 능력과 집행기능 간 상 관성을 분석하였으며, 그 결과 정보 처리 속도를 주로 반영하는 $\mathrm{K}-\mathrm{TMT}-\mathrm{E}$ 의 A형 반응시간과의 정적 상관을 확인하였다. 추후 연구에서는 난청 집단뿐만 아니라 정상 노인 집단에 대해서도 상관 분석을 실시하여 두 집단 간 결과를 비교할 필요가 있을 것이다. 두 집단 간 다른 양상이 확인된다면 난청 여부에 따라 노년층의 생성이름대기 처리 과정에 작용하는 전두엽-집행기 능의 양상에 차이가 있음을 확인할 수 있을 것이다. 셋째, 본 연구에서는 난청 노인과 정상 청력의 노인 집단 간 평균 연령에 차이가 나타나 통계적인 방법을 사용하여 연령의 영향을 통제 하고자 하였으나, 그럼에도 불구하고 연령의 영향을 모두 배제 하였다고 하기에는 다소 무리가 있다. 추후 연구에서는 가능한 한 두 집단 간 인구통계학적 특성을 대응시켜 노년층의 단어 유창성에 대한 난청의 영향을 좀 더 명확히 파악하는 것이 필 요하겠다. 넷째, 본 연구에서는 난청 노인 집단의 청력을 세분화 하지 않았는데, 난청 정도에 따라 언어 및 인지기능에 차이를 보일 수 있으므로(Deal et al., 2015), 추후 연구에서는 난청 정 도에 따라 대상자 집단을 분류하여 집단 간 단어 유창성에 차 이가 나타나는지 살펴볼 수 있을 것이다. 끝으로, 본 연구에서 는 전두엽-집행기능을 평가하는 검사로 서울신경심리검사2판 에 포함된 K-TMT-E와 K-CWST의 두 가지 검사만을 시행하 였다. 집행기능을 이루는 인지적 요소가 다양한 만큼(Salthouse, 2005), 추후 연구에서는 집행기능 하위 영역에 따라 다 양한 과제를 활용함으로써 단어 유창성 능력과 집행기능의 세 부적인 요소 간 상관성을 파악하는 것이 고려되어야 할 것이다. 
중심 단어 : 단어 유창성·난청·전환·군집·전두엽-집행기능.

\section{Ethical Statement}

This study was approved by the Institutional Review Board of Tongmyong University (IRB\#. 201809-HR-001).

\section{Acknowledgments N/A}

\section{Declaration of Conflicting Interests}

There are no conflict of interests.

\section{Funding}

This research was supported by the Tongmyong University Research Grants 2019 (2019A008).

\section{ORCID iD}

Soo Jung Lee

$$
\text { https://orcid.org/0000-0003-0954-5181 }
$$

\section{REFERENCES}

Classon, E., Löfkvist, U., Rudner, M., \& Rönnberg, J. (2014). Verbal fluency in adults with postlingually acquired hearing impairment. Speech, Language and Hearing, 17(2), 88-100.

D'Ausilio, A., Craighero, L., \& Fadiga, L. (2012). The contribution of the frontal lobe to the perception of speech. Journal of Neurolinguistics, 25(5), 328-335.

Deal, J. A., Sharrett, A. R., Albert, M. S., Coresh, J., Mosley, T. H., Knopman, D., et al. (2015). Hearing impairment and cognitive decline: A pilot study conducted within the atherosclerosis risk in communities neurocognitive study. American Journal of Epidemiology, 181(9), 680-690.

Diamond, A. (2013). Executive functions. Annual Review of Psychology, 64, 135-168.

Henry, J. D. \& Crawford, J. R. (2004). Verbal fluency deficits in Parkinson's disease: A meta-analysis. Journal of the International Neuropsychological Society, 10(4), 608-622.

Ho, A. K., Sahakian, B. J., Robbins, T. W., Barker, R. A., Rosser, A. E., \& Hodges, J. R. (2002). Verbal fluency in Huntington's disease: A longitudinal analysis of phonemic and semantic clustering and switching. Neuropsychologia, 40(8), 1277-1284.

Homans, N. C., Metselaar, R. M., Dingemanse, J. G., van der Schroeff, M. P., Brocaar, M. P., Wieringa, M. H., et al. (2017). Prevalence of age-related hearing loss, including sex differences, in older adults in a large cohort study. The Laryngoscope, 127(3), 725-730.

Kang, Y. W. (2006). A normative study of the Korean Mini-Mental State Examination (K-MMSE) in the elderly. Korean Journal of Psychology: General, 25(2), 1-12.

Kang, Y. W., Chin, J. H., Na, D. L., Lee, J. H., \& Park, J. S. (2000). A normative study of the Korean version of Controlled Oral Word Association Test (COWAT) in the elderly. Korean Journal of Clinical Psychology, 19(2), 385-392.

Kang, Y. W., Jang, S. M., \& Na, D. L. (2012). Seoul Neuropsychological Screening Battery (SNSB). (2nd ed.). Seoul: Human Brain Research \& Consulting Co.

Kim, J. (2016). Variables affecting on generative naming of middle-aged and elderly people: Working memory, executive function, education level (Unpublished master's thesis). Yonsei University, Seoul.

Lee, J. H., Kang, Y. W., \& Na, D. L. (2000). Efficiencies of stroop interference indexes in healthy older adults and dementia patients. Korean Journal of Clinical Psychology, 19(4), 807-818.

Lee, M. S. \& Kim, B. S. (2019). Characteristics of word fluency in healthy aging and Alzheimer's disease. Audiology and Speech Research, 15(2), 135-143.

Lee, S. H., Kim, H., Kim, J., Yoon, J. H., \& Kim, S. R. (2015). Initial phase performance in a 30-s verbal fluency task as being reflective of aging effect. Geriatrics and Gerontology International, 15(4), 496-500.

Lee, S. J. (2018). The relationship between hearing impairment and cognitive function in middle-aged and older adults: A meta-analysis. Communication Sciences and Disorders, 23(2), 378-391.

Lee, S. J., Park, K. W., Kim, L. S., \& Kim, H. (2018). Association between frontal-executive dysfunction and speech-in-noise perception deficits in mild cognitive impairment. Journal of Clinical Neurology, 14(4), 513522.

Lee, S. M., Yoon, J. H., \& Lee, S. J. (2018). Characteristics and underlying mechanisms of semantic clustering in Parkinson's disease. Communication Sciences and Disorders, 23(3), 647-659.

Mathuranath, P. S., George, A., Cherian, P. J., Alexander, A., Sarma, S. G., \& Sarma, P. S. (2003). Effects of age, education and gender on verbal fluency. Journal of Clinical and Experimental Neuropsychology, 25(8), 10571064.

McCabe, D. P., Roediger, H. L., McDaniel, M. A., Balota, D. A., \& Hambrick, D. Z. (2010). The relationship between working memory capacity and executive functioning: Evidence for a common executive attention construct. Neuropsychology, 24(2), 222-243.

Moscovitch, M. (1994). Cognitive resources and dual-task interference effects at retrieval in normal people: The role of the frontal lobes and medial temporal cortex. Neuropsychology, 8(4), 524-534.

Park, J., Kang, Y., Chang, E. J., Oh, E., Yu, K. H., \& Lee, B. C. (2006). Clustering and switching on verbal fluency in vascular dementia and dementia of the Alzheimer's type. Communication Sciences and Disorders, 11(3), 99-112.

Park, J., Kang, Y., Yi, H., Kim, Y. J., Ma, H. I., \& Lee, B. C. (2007). Usefulness of the Korean Trail Making Test for the elderly (K-TMT-e) in detecting the frontal lobe dysfunction. Dementia and Neurocognitive Disorders, 6(1), 12-17.

Park, J. J. \& Yoon, J. H. (2015). Word-finding strategies on generative naming in normal elderly. Journal of Rehabilitation Research, 19(2), 339360.

Peach, R. K. \& Shapiro, L. P. (2012). Cognition and Acquired Language Disorders: An Information Processing Approach. St. Louis, MO: Elsevier.

Rönnberg, J., Rudner, M., Lunner, T., \& Zekveld, A. A. (2010). When cognition kicks in: Working memory and speech understanding in noise. Noise and Health, 12(49), 263-269.

Salthouse, T. A. (2005). Relations between cognitive abilities and measures of executive functioning. Neuropsychology, 19(4), 532-545.

Scarpina, F. \& Tagini, S. (2017). The stroop color and word test. Frontiers in Psychology, 8, 557.

Shao, Z., Janse, E., Visser, K., \& Meyer, A. S. (2014). What do verbal fluency tasks measure? Predictors of verbal fluency performance in older adults. Frontiers in Psychology, 5, 772.

Troyer, A. K., Moscovitch, M., \& Winocur, G. (1997). Clustering and switching as two components of verbal fluency: Evidence from younger and older healthy adults. Neuropsychology, 11(1), 138-146.

Troyer, A. K., Moscovitch, M., Winocur, G., Alexander, M. P., \& Stuss, D. (1998). Clustering and switching on verbal fluency: The effects of focal frontal- and temporal-lobe lesions. Neuropsychologia, 36(6), 499-504.

Wayne, R. V. \& Johnsrude, I. S. (2015). A review of causal mechanisms underlying the link between age-related hearing loss and cognitive decline. Ageing Research Reviews, 23(Pt B), 154-166.

Whiteside, D. M., Kealey, T., Semla, M., Luu, H., Rice, L., Basso, M. R., et al. (2016). Verbal fluency: Language or executive function measure? Applied Neuropsychology: Adult, 23(1), 29-34.

Wild, C. J., Yusuf, A., Wilson, D. E., Peelle, J. E., Davis, M. H., \& Johnsrude, I. S. (2012). Effortful listening: The processing of degraded speech depends critically on attention. Journal of Neuroscience, 32(40), 1401014021.

Yi, H., Chin, J., Lee, B. H., Kang, Y., \& Na, D. L. (2007). Development \& validation of Korean version of trail making test for elderly persons. $D e$ mentia and Neurocognitive Disorders, 6(2), 54-66. 


\section{APPENDIX $\square$}

\section{동물 하위 범주 분류 및 예시}

\begin{tabular}{|c|c|c|}
\hline \multirow{3}{*}{ 서식 환경 } & $\begin{array}{c}\text { 동물원에서 } \\
\text { 볼 수 있는 동물 }\end{array}$ & $\begin{array}{l}\text { 호랑이, 사자, 기린, 코끼리, 원숭이, 오랑우탄, 판다, 코알라, 토끼, 사슴, 늑대, 여우, 뱀, } \\
\text { 코브라, 낙타, 하마, 물개, 돌고래, 코뿔소, 말, 얼룩말, 악어, 표범, 곰, 치타, 캥거루, 공작새 }\end{array}$ \\
\hline & 물속에 사는 동물 & 하마, 물개, 수달, 물소, 돌고래, 악어 \\
\hline & 야생동물 & $\begin{array}{l}\text { 산돼지, 멧돼지, 너구리, 오소리, 쥐, 고라니, 노루, 사슴, 다람쥐, 꿩, } \\
\text { 담비, 곰, 늑대, 두더지 }\end{array}$ \\
\hline \multirow{8}{*}{ 동물 종류 } & 포유류 & 사슴, 돼지, 말, 낙타, 코끼리, 염소, 표범, 노루 \\
\hline & 조류 & $\begin{array}{l}\text { 참새, 오리, 거위, 칠면조, 타조, 닭, 비둘기, 황새, 까치, 까마귀, 제비, 공작새, 뻐꾸기, } \\
\text { 갈매기, 독수리, 매, 부엉이, 기러기, 학, 펭귄 }\end{array}$ \\
\hline & 어류 & $\begin{array}{l}\text { 장어, 참돔, 꽁치, 고등어, 도다리, 붕어, 잉어, 상어, 고래, 갈치, 가자미, 전어, 조기, 메기, } \\
\text { 미꾸라지, 대구, 멸치, 해삼, 전복, 굴 }\end{array}$ \\
\hline & 곤충류 & 잠자리, 벌, 매미, 하늘소, 개미, 거미, 무당벌레, 나비 \\
\hline & 설치류 & 다람쥐, 쥐, 청설모, 토끼, 두더지 \\
\hline & 파충류/양서류 & 개구리, 거북이, 뱀, 도마뱀, 코브라 \\
\hline & 영장류 & 원숭이, 고릴라, 침팬지, 오랑우탄 \\
\hline & 무척추동물 & 지렁이, 달팽이 \\
\hline \multirow{3}{*}{ 인간의 사용 } & 농장동물(가축) & 닭, 소, 개, 돼지, 양, 말, 토끼, 거위, 오리, 염소 \\
\hline & 애완동물 & 강아지, 고양이, 병아리, 햄스터 \\
\hline & 짐을 드는 동물 & 당나귀, 말, 황소, 낙타 \\
\hline \multicolumn{2}{|r|}{ 기타 } & 토끼-거북이; 고양이-쥐 \\
\hline
\end{tabular}

